\title{
The Quest for Social Justice and Multiculturalism: from the Perspective of Gender Alterity
}

Xie Huiyuan (Tsinghua University)

Yet if I had realized how fantastically fast that would really happen -

already in less than ten years' time — maybe I would have been so sacred I might have stopped writing. It's frightening when you're starting on a new road that no one has been on before. You don't know how far it's going to take you until you look back and realize how far, how very far you've gone. ${ }^{(1)}$

- Betty Friedan

In the introduction to the tenth anniversary edition of her book The Feminine Mystique, in 1973, Betty Friedan expressed her surprise at the rapid and great changes of the world influenced by the female. What on earth has it changed? And how has it changed up till now? This paper attempts to discuss the way in which the issues of alterity affect our understanding of the questions related to social justice and multiculturalism, from the perspective of gender. ${ }^{(2)}$

The paper is in four sections. The first presents a brief sketch of the idea of gender alterity, indicating its purpose to spell out female voices and struggle for necessary concerns. The second and the third part elaborate the quest of feminism for social justice and multiculturalism in western countries and in China. And the fourth analyzes the value of gender alterity which challenges our understanding of social justice and enables us to have a more tolerable attitude to multiculturalism. 


\section{Women as Gender Alterity}

I will begin by exploring the idea of alterity and gender alterity in the context of feminism theories.

Comparing to "the Subject", the central concern with alterity is what might be described as the moral significance of "the Others". The Others challenge a certain kind of mainstream identity, that is, to what extent the sameness could be identified and is it possible such identity dominate our ideas of the world. Here I don't mean that the idea of alterity undermines or even denies the value of identity. As a matter of fact, the ideas of alterity and identity are relevant, though with different definitions, because both of these two concepts imply particularity and common goods shared by the members of a political or cultural community, and their particularity is of consistency and continuity, to some degree. "The attitude of this generalized Others", as Mead puts it, "is that of the entire community", and "the Other becomes constitutive of identity" ${ }^{(3)}$ With the self-consciousness, the Other not only mirrors the mainstream identity, but also aims to spell out other voices and struggle for necessary and equal concerns, to set free from the subordinate position, and to transform the existing paradigms, rather than to supplement or subordinate itself to the mainstream ideologies. So the concept of alterity emphasizes somewhat difference, decentralization and pluralism.

From the perspective of gender, alterity indicates the difference between men and women at least. Different from sex, gender is the cultural interpretation and social discourse which is changeable under certain circumstances. And the concrete meaning of gender embodies its social construction and culture sometimes. So any changes of the ideas about gender will have influence on the identities of men and women, and then on the culture and the society. Contrary to the standpoint of 
biological fundationalism, some feminists do not regard gender as the result of natural function unchangeably. As Simone de Beauvoir, in The Second Sex, holds that, "One is not born, but rather becomes, a woman." (4) And they also believe gender alterity implies the subordination and nonmainstream of women in the patriarchal society, and the gender difference is in a hierarchical order, where the masculine is always the favored standards and the femininity becomes positioned as "the Other". Being "the Other", women depending on men are marginalized silently and secretly, having few opportunity to express their dissatisfaction in the past.

When women are concerned with their unfair position, something needs to be changed. And feminism is among the critical impetuses for the reconstruction of a just society, theoretically and practically. Therefore, gender alterity challenges the conservatism and conformism of a society, and makes it possible to accept more comprehensive ideas of social justice and multiplicity.

\section{The Quest of Gender Alterity for Social Justice and Multiculturalism in Western}

Justice pertaining to the social and juridical ideals is an important standard of a well-order society. How our life would be is based on our imagination of how a just society should be. Philosophers, from Ancient Greek to the contemporary, keep on discussing the principles of justice and the ways in which we can make a just society come true. So do women and feminists. As a particular community with social disadvantage, feminism expresses the voices of somewhat of multiculturalism.

During the earlier period, feminists compatible with the liberal political theories, such as Mary Wollstonecraft, Elizabeth Stanton and Emma Goldman, criticized the unjust status of women, regarded equality as the fundamental principle of justice, demonstrated women should be 
provided the same rights and opportunities as men had got, and believed just institutions should be neutral to gender and entitle women to the equal citizenship and the rights of vote, education and employment. They looked back to the history of politics and the actual roles of women in public life, and found out women had not be allowed to participate in politics at all and women were never defined as independent person but in relation to men. With the weakness of nature, women were taught that what they should have were the virtues to take care of their children and husbands, what they should care about were pots and pans, furniture and gardens, clothing and cosmetics, and what femininity they should be with was being attractive to boys, softness and grace of temper, fondness for dress, passive and frivolous, and so on. In a word, they were limited in families and were excluded from public affairs. Men monopolized the public positions and decided the policies related to men themselves and women. In Declaration of Sentiments, Elizabeth Stanton lists several facts to prove that "the history of mankind is a history of repeated injuries and usurpations on the part of man toward woman, having in direct object the establishment of an absolute tyranny over her." ${ }^{(5)}$

But women should not be misled by illusion of their weakness, and they need to step out of their kitchens and fight for their rights in public domain where men had dominated for decades. As Firestone puts it, "the only way to break away from oppression is to use technological advances to free themselves from the burden of childbirth, breaking down the biological bond between mothers and children and establishing communes where monogamy and the nuclear family are things of the past." (6) Her idea shows that feminists denies the female particularity and there are no difference between men and women, so women could fulfill their obligations in public realm as perfect as men do. Based on the sameness, women should earn back their equal rights and opportunities 
which have been deprived of by men, and share the social distribution with men. In practice, women imitated the styles of male speech and male behavior, such as dirty words, smoking or dressing like a man, and they also gained the vote in 1920 in the United States. Consistent with the liberalism framework, the concept of justice is regarded as equality and feminists in this period appreciate the homogeneity with men, without the consciousness of their gender alterity.

Gender alterity was concerned later by the feminists, such as Virginia Woolf, Iris Young and Barbara Arneil. They went beyond liberalism and identify the particularity of women with which feminine should be based on feminine, rather on masculine femininity. That is to say, feminists at the second stage are conscious of their alienation to men and confirm the difference between men and women, no matter in sex or in gender. In this sense, Moira Gatens points out that "the male body and the female body have quite difference social value and significance cannot help but have a marked effect on male and female consciousness". ${ }^{(7)}$ And the diversity and difference were defended and emphasized by the postmodern feminists, such as Kristeva and Irigaray ${ }^{(8)}$. But the commitment to natural difference does not justify the female subordination. Since the existing institutions embodied the hierarchical order and the cultural hegemony of the patriarchy prosperities, and a certain kind of hypothetical standards were passed through to favor the male, as if they were objective and general, feminists insisted that they had lived in an unjust society, and the subversion against the idea of justice in patriarchal society was needed. Concerned with the reconstruction of social justice, feminists with diverse theories, such as liberal feminists, socialist feminists, Marxism feminists, radical feminists, existentialist feminists and psychoanalytical feminists, discussed the problems ranging from the ontological topic about "identity" and "alterity" to the practices relevant to reproduction, labor abortion, 
sexuality, rape and domestic violence.

These plural claims had been intensified by the feminists characterized as "generation X", who confess "the complex, multi-issue nature of our lives" ${ }^{(9)}$ since the mid-1990. And their emphasis on gender alterity implies dualism or pluralism and results in the question like that, how could the disagreements or conflicts sit together peacefully? Is it possible for people with different viewpoints negotiate and make agreements? And whether feminists with diverse theoretical framework, as I mention above, harmonize and unify together?

The voices of women and the claims of feminists indicate the invocation upon adequate attention to "the Other" and the subversion against the understanding of the questions related to social justice in patriarchal society. And the perspective of gender alterity and the diversity of feminist arguments permeate the necessity to cope with multiplicity of ideas and culture.

\section{The Quest of Gender Alterity for Social Justice in China}

Compared with those women movements in western countries, the claims on liberty and equality of women in China could be characterized as more than the struggle by women themselves.

Affected by the beliefs in "all men are created equal", the intellectuals in the late nineteenth century ${ }^{(10)}$ criticized the unfair discrimination and cruel oppressions on women by Feudalism, and argued that women should be entitled to education and be free from the bizarre and terrible custom of foot-binding. The advocators of the Constitutional Reform and Modernization of 1898, such as Kang Youwei and Liang Qichao, regarded the equality between women and men as a part of reformation against Feudalism. Because of its focus on modernization rather than the liberation of women and its failure, the reformation did not have much influence on 
the consciousness of gender alterity. Not many women were against their unequal status until the period of Chinese Revolution of 1911. With the anti-inequality propaganda, many middle-class women were acknowledged about their unfortunate situation, and condemned the traditional culture and social institutions for equal rights. However, there were also more than 200 million women of lower class still followed the idea that men were superior over women. Similar to struggle at first stage of in western, patriarchy had been accepted and gender alterity had not been realized.

The great changes happened in 1915, when the New Culture Movement was launched. During this period, the feudalism morality and rituals, characterized by "San Chong Si De" (11), were challenged rapidly. And lots of literatures widely discussed the misery of women at that time and claim for the reconstruction of a just society. The slogans, such as "fighting for the rights of women" and "seeking for equality" encouraged women to struggle for their liberation theoretically and practically. Enlightened by the new culture, more and more people were aware of the necessity of the liberation of women. Some women were provided with the opportunity of education, and a few of female intellectuals in urban areas were independent economically since they were employed. Moreover, they believed the access to political participation could symbolize their independence and equality, and argued that "with the dependence on the favor and mercy from men, women are doomed to the indignity and unfairness if they do not seek for their power in politics" ${ }^{(12)}$. And the idea of political equality was confirmed by the "Common Program" when People Republic of China was founded in $1949^{(13)}$. During the period of 1950s to 1970s, women thought there were no difference between men and women and they were competent for the positions which had allocated for men. For example, most women were dressed in military uniforms rather than skirts and participate in the revolution and the political movements 
with men at that time. It was until 1970s that women had a clearer idea of gender alterity, and the researches on gender were discussed widely from then on.

Let's consider the cases about the distribution ${ }^{(14)}$ of lands to discuss how women as gender alterity defend their equal rights for justice. It is well-known that, in some villages in countryside, a woman married with a husband who has not registered in her village will be deprived of her lands allocated before, because the prejudice that a woman subordinate to her husband and there is little relationship between the woman with her clan after she marries. Such traditional deprivation is accepted as a reasonable and feasible custom by both men and women, though it not only intensifies the dependence of women on their husbands, but also aggravates the inequality between men and women. With the consciousness of "gender equality", many women defend their rights by the intermediations and lawsuits ${ }^{(15)}$. These cases attract the public attention, and the government legislates against the illegal occupation of the lands distributed to the married women to protect their equal rights.

With the development of the quest for social justice in China, we can find out the challenges to the unjust society and the inequality between men and women, which are parts of the reformation or revolution for the freedom from Feudalism and Imperialism, are supported by intellectuals and the government rather than only by women themselves. And the policies concerned with social justice as equality and fairness are carried out in advance, which contributes to women's awareness of gender.

\section{The Challenges to the Understanding of Social Justice and Multiculturalism}

Based on the theories and the practices above, we can find that the original viewpoints about justice enlarge the comprehension of justice 
and enrich its meaning, and reflect the challenge of gender alterity to the understanding of social justice.

First of all, as the gender alterity, women express another voice against the injustice in the society dominated by men, and spell out their thoughts and their requirements for a just society. In the past, when phallocentric mode prevailed and the social structure and institutions were built on such basis, women were confined by households and dependent on their fathers, their husbands and their sons physically and psychologically. Therefore, they accepted the patriarchal traditions and suffered from the "nameless aching dissatisfaction alone for many years" ${ }^{(16)}$. What worse was that women had no chances to say no, though they sometimes felt dissatisfied, bored, agonized, or even being harmed, since such a living paradigm was emphasized by the institutions and education, and they all believed it was their duties to follow the men who superior to them in nature. The female "reality subsists somewhere beneath the socially real — totally exposed but invisible, screaming yet inaudible, thought about incessantly yet unthinkable, 'expression' yet inexpressible, beyond words" (17) . Each suburban wife struggled with it alone", Friedan describes, "as she made the beds, shopped for groceries, matched slipcover material, ate peanut butter sandwiches with her children $\cdots \cdots$ lay beside her husband at night - she was afraid to ask even of herself the silent question- Is this all'?" (18) It is not all for all women, in the opinion of feminists, but all for those women in a patriarchal society. Contrary to the monologue of men years ago, the consciousness of gender alterity helps women know more about their identity, merits and unfair positions, enables them unite together, and provides the ways in which they could negotiate with men and discuss how a just society should be and what kind of life should be valued.

In order to justify the equal ability and status of women, the physical 
and psychological roots of justice have been reconsidered, and the rights to reconstruct idea of social justice in public are entitled. As we know, women were deemed the weaker sex because they were less rational and more emotional, by the philosophers such as Plato, Aristotle, Rousseau and Kant. "Though all persons possess in common different parts of the soul, they possess them in different ways", as Aristotle puts it in Politics, "the slave is entirely without the faculty of deliberation; the female indeed possesses it, but in a form which remains inconclusive; and if children also possess it, it is only in an immature form". The hierarchical nature justified to the relations of "ruling and being ruled", and the female as "the lower always exist for the sake of the higher" ${ }^{(19)}$ with of their natural defective. Because of the weakness, women were excluded from the public affairs and social justice was only considered in the standpoint of the male in the public sphere, so it seemed that women had nothing to do with justice. A case in point is the experience of Wu Zetian, the unique female emperor in China, who suffered from continuous objections against her government, and her empire was overthrown before long. However, the hypothesis of female weakness of "reason" and the idea of functionalism has been denied by feminists. Some of them cherish the female merits, including the ability of reason. When criticizing the prejudices hold by Rousseau and Dr. Gregory, Wollstonecraft claims it is nonsense to rest on the socalled nature and dependence on men, and the virtues of women and men are same in quality, so "their conduct should be founded on the same principle, and have the same aim", with the fair opportunities of education (20) . Accordingly, they recount the contemporary theories of justice and advocated reforming the male-dominant institutions, in order to participate in the public issues and making decisions.

One of the theories of justice feminists criticize is that of Rawls. When Rawls, in his book $A$ Theory of Justice, defines justice as "the first virtue 
of social institutions, as truth is of systems of thought" ${ }^{(21)}$ and argues that "all social primary goods" are to be distributed equally unless an unequal distribution of any or all of these goods is to the advantage of the least favored" ${ }^{(22)}$, it seems "egalitarian plateau" ${ }^{(23)}$ has been shared widely in contemporary political philosophy. With the veil of ignorance, people could sign contracts to share goods equally in the original position. But such original position ignores the difference between men and women so much, as far as feminists are concerned, that it is too ideal to be realized and women are unable to "have an equal right to the most extensive basic liberty compatible with a similar liberty for others", ${ }^{(24)}$ as the first principle indicates. In fact, neither social and economic inequalities are to be arranged so that they are "reasonably expected to be to everyone's advantage", nor are they "attached to positions and offices open to all" (25) So is it fair to say that? And is it fair to be indifferent to the disadvantages of women in the case of unemployment and non-education? Putnam argues that the original position is the monologue of the male, or more exactly, the monologue of white high-class and heterosexual men, and the contracts, such as employment ones, are signed on the basis of gender relations of domination and subordination, embodying the patriarchy prosperities, rather than free agreement between equal parties. ${ }^{(26)}$ Based on their statement, we can see that, "reason" is not regarded as the premise of the participation to public sphere and not as the unique standard of justice. In a just society, not only equal rights and opportunities should be provided feasibly and practically for women to realize their values in public, but also women as the less fortunate, resulting from the historical discrimination and subordination, should be compensated and taken care of by just institutions, to some degree.

Besides the justice in public domain, women quest for the justice in private life as well. As I analyze above, justice was a political concept only 
and never considered applicable in patriarchal family, and men were the heads both in public affairs and in private ones because of their "reason" and their economic security for family members. In such traditional phallocentric mode, though women were burdened with exhaustive household, taking care of their husbands and children, their labors were undervalued by those men she had served. They were "sedutive and impenetrable female representative of the dark and magic underwater world from which our life comes and in which we cannot live". ${ }^{27)}$ The undervaluation of their work is the result of the duality of public sphere and private one, which lead to the misunderstanding of justice by ruling it out of the family issues. Consider Rawls' theory of justice again. When he explains the primary subject of justice as "the basic structure of society, or more exactly, the way in which the major social institutions distribute fundamental rights and duties and determine the division of the advantages from social cooperation", in the opinion of feminists, he actually does not take family into account ${ }^{(28)}$. What he focuses on is the construction of social justice in public sphere and his theory of contracts does not gone beyond those hold by classical philosophers who are in the grip of social contracts but do not care about those related to sex at all. Furthermore, the sexual contracts are unequal, as Stanton objects to, and women are the less fortunate contractor because women are totally dependent on men and do not share the equal rights in family.

Based on the value of women in private sphere, some feminists, such as Nussbaum and Okin, illuminate that family is a part of the society, so it is necessary to extend the range of justice to private life, not only for the sake of women themselves, but also for the sake of the integrity of the just society as a whole ${ }^{(29)}$. The intervention of government in private life, therefore, should be legitimate to ensure the principles of justice protect the rights and equality of women in private domain as well. For example, 
the sexual contracts should be signed equally and be protected legally, and the rape and the violence should be punished.

Moreover, the awareness of gender alterity and the particularity of women also enlighten new insights for us to understand the issues of justice more comprehensively. Uncovering the biases of traditional contracts, feminists find out these contracts are accessible on condition that citizens are full of "reason" and the citizens are imagined to be able to calculate accurately what should be done and maximize their benefit for the purpose of justice. But the ideas relevant to "rational contracts" and "rational contractors" (or "economic men") are taken the place by the concepts of "motherhood" and "mothering person" ${ }^{(30)}$ with gender-neutral standpoint by Virginia Held. Since the solicitous and emotional relationship between mothering person and child will benefit us by avoiding "the distortions arising from imaging the purely voluntary trades entered into by rational economic contractors to be characteristic of human relations in other domains" ${ }^{(31)}$ and by enabling the reciprocal obligations of one another, the society reconstructed by mothering persons would be just and the relation characterized by "care" would remedy the inadequacy of contractual relations. Besides the notion of social justice on the basis of care ethics, Christine Littleton outlines a society with "equality as acceptance", aiming "to make gender differences, perceptive or actual, costless relative to each other, so that anyone may follow a male, female, or androgynous lifestyle according to their natural inclination or choice without being punished for following a female lifestyle or rewarded for following a male one." ${ }^{(32)}$

The challenges to our understanding of social justice are composed of various voices from women and feminists, and it is these challenges that contribute to the quest of multiculturalism externally and internally. In Simmel's opinion, women are alien to the methods and the principles of 
culture because of their vulnerability to emotion and unsteadiness which is in contradiction with the quality of culture characterized by steadiness and consistency, hence, culture is constructed by men and has nothing to do with women. However, the domination of culture hegemonism is questionable. Though marginalized from the beginning, feminists evoke themselves into a broad-based community as the alterity contrary to the mainstream patriarchal culture, by criticizing the phallocentric paradigm of gender and claiming for adequate attention and protection. The arguments against the phallocentric imposition develop the neo-culture beyond that of patriarchy and become a part of multiculturalism. Moreover, with the marriage to diverse political theories, there are different or even disputable arguments on a certain problem, which also embodies the pluralism of concerns and conclusions.

So how should we cope with the difference, and how could we harmonize the arguments in conflict and make them sit together tolerably? And it is the situation that feminists have to handle if they want to reunite multiple feminisms in contemporary. Since the expressions from women are so multiple, their ideas on the settlement will help us have a more feasible and reasonable way in which multiculturalism should be treated. Generally, the settlement could be categorized roughly. Some feminists suggest it is necessary to face difference with tolerant attitude and treat women in different groups, regardless of their race, social class, health and religion, equally. For example, Robin Morgan believes the differences among women are fewer than they seem to be, and women could identify their homogeneity if they could be heard mutually sincerely; therefore, women in the world are in sisterhood ${ }^{(33)}$. Iris Young suggests that "a politics of different lays down institutional and ideological means for recognizing and affirming differently identifying groups in two basic senses: giving political representation to group interests and celebrating 
the distinctive cultures and characteristics of different groups" ${ }^{(34)}$. But some other feminists, such as Elizabeth Spelman, say it is a unilateral illusion to hold that women could ignore their individual particularity for homogenous identity and the differences among them are antagonistic. Although the problems related with multiculturalism have not been solved completely, the insights of feminists will throw some lights on it.

\section{Conclusion}

As gender alterity, women and feminists spell out their claims to equality and justice by overturning the social arrangement of politics, morality and culture, and challenge our understanding of the questions related to how a just society should be constructed. The female voices, which have been anonymous, represent the commitments from half the global population, their status of subordination have been transforming in a subversive way, no matter in public sphere or in private sphere, and their ideas about the care ethics enlarge the comprehension of social justice. And these challenges also help us know more about the value of multiculturalism in the era of globalization, when democratic dialogues among rational citizens are more and more popular.

\section{Notes}

(1) Friedan, Betty (1997), The Feminine Mystique. New York: Norton \& Company Ltd. P7

(2) I acknowledge in advance that I am not quite sure whether the direction of feminism is the right one, but its original perspective is the enlightenment for us to have a more comprehensive insight into multiculturalism and justice.

(3) Mead, George Herbert (1973) Geist, Identität und Gesellschaft aus der Sicht des Sozialbehaviorismus. Frankfurt a.M.: Suhrkamp, cited from Welz, Frank. Identity and Alterity in Sociological Perspective. www.zmk.uni-freiburg.de/Online_Texts/ Welz_Identity.pdf

(4) Beauvoir, Simone (1972). The Second Sex. translated by H. M. Parshley, Penguin. 


\section{生存学研究センター報告 4}

p295

(5) In Declaration of Sentiments, Elizabeth Stanton shows fifteen points about how men dominated and oppressed women. See, Stanton, Elizabeth. (2000) . Declaration of Sentiments, in Feminist Theory: A Reader. compiled by Wendy Kolmar and Frances Bartkowski. California: Mayfield Publishing Company

(6) Firestone, Shulasmith (1970). The Dialectic of Sex: The Case for Feminist Revolution, London: The Women's Press

(7) Gatens, Moira (1996). Imaginary Bodies: Ethics, Power and Corporeality, London: Routledge, p9

(8) Kristeva, Julia (1992), Desire in Language: A Semiotic Approach Literature and Art. in Maggie Humm (ed.), Feminisms: A Reader, Hemel Hempstead: Harvester Wheatsheaf. Luce Irigaray (1996), Irigaray, Luce. The Sex Which is Not One. in Lawrence Cahoone (ed.), From Modernism to Postmodernism: An Anthology, Oxford: Blackwell.

(9) Walker, Rebecca (1995) (ed.). To Be Real: Telling the Truth and Changing the Face of Feminism. New York: Anchor Books. p xxxviii.

(10) Though some of the policies indicated that women should be equal with men in the Taiping Heavenly Kingdom in 1850s, they were put into effects for the sake of the protection against the Qing Dynasty and had been denied when the Kingdom was overthrown.

(11) Generally, "San Chong" means that, as a girl unmarried, she should act according to what her father, told her and should not disobey her parents without expostulation; when married, she must be faithful to her husband until he died, no matter whether she had been harmed by violence or not; and when her husband died, she ought to keep single to nurture her children and rely on her sons. Generally "Si De" implies the femininity of virtues, speech, appearance and labor. "Si De'refers to ", as Zheng Xuan put it, "the chastity to her husband, obedience to her parents in law, speaking in a subservient way, not to be a gossip, diligence to household, keep tidy appearance. The traditional custom of "San Chong Si De" showed the ritual and elegance of women on one hand, but also implied the subordination of women in patriarchy on the other hand. So women in noble families had to bind their feet unnaturally and show their delicate appearance, for the male satisfaction. And women in lower class had to do the unpaid work, such as serving their parents (in law), husbands and children, being busy with needlework and feeding cattle or silkworms. Moreover, their subordination could be embodied out of family. For instance, they were deprived of the opportunity of education and it was one of the female virtues to be ignorant. And it was a taboo for women to participate in the public affairs, especially those related to the state-government.

(12) The Declaration by the League of the feminist movement in Beijing. 
(13) There were 69 women (more that $10 \%$ of the representatives) taking part in the Chinese People's Political Consultative Confess in 1949, and Song Qingling held the position as a female vice chairman.

(14) The "distribution" of lands means that farmers are entitled to cultivate their lands on condition that they sign contracts, rather than that they completely have the ownership of lands.

(15) According to the statistics, about 748 cases relevant to the disputes of landdistribution had been put forward in Guangdong Province in 2001.

(16) Friedan, Betty (1997), The Feminine Mystique. New York: Norton \& Company Ltd. P33

(17) Catharine A. Mackinnon (2002). Only Words. Cambridge: Harvard University Press, p6

(18) Friedan, Betty (1997), The Feminine Mystique. New York: Norton \& Company Ltd. P15

(19) Aristotle (1946 ). Politics. I 1260a10, 1333a20-21, 1254a24-33, translated by E. Baker, Oxford: Clarendon Press

(20) Mary Wollstonecraft (1995). A Vindication of the Rights of Women. ed. by Sylvana Tomaselli, Cambridge: Cambridge University Press, pp90-97

(21) Rawls, John (1971). A Theory of Justice. Beijing: China Social Sciences Publishing House, P3

(22) Ibid., P303

(23) Kymlicka, Will (2002). Contemporary Political Philosophy: An Introduction (2nd edition). Oxford: Oxford University Press, p377

(24) Rawls, John (1971). A Theory of Justice. Beijing: China Social Sciences Publishing House (reprinted).p60

(25) Ibid.p61

(26) Pateman, Carole (1988).The Sexual Contract, Cambridge: Polity

(27) Dinnerstein, Dorothy (1977), The Mermaid and the Minotaur, New York: Harper Colophon Books, p5

(28) Though Rawls claims that parents should be equal and families are also important to cultivate children to develop their sense of justice and virtue, when he responds to the criticism of feminists in Fairness as Justice, feminists think he has ruled out the role of family.

(29) During the period of 1960 s, radical feminists pay much attention to the unfortunate of women, challenge the existing division of labor, and raise the idea that "the personal is political" because they were acknowledged that private life was far from being apolitical.

(30) Held, Virginia (1993). Feminist Morality: Transforming Culture, Society, and Politics. Chicago: The University of Chicago Press. pp197-198 


\section{生存学研究セン夕ー報告 4}

(31) Ibid. pp204-211

(32) Littleton, Christine (1987). Reconstruction Sexual Equality, California Law Review. Vol. 75, p1297

(33) Morgan, Robin (1996) (complied and edited). Sisterhood in Global: The International Women's Movement Anthology. New York: The Feminist Press.

(34) Young, Iris Marion (1981). The Ideal of Community and the Politics of Difference. In Linda J. Nicholsen (ed.), Feminism/Postfeminism. New York: Routledge. 